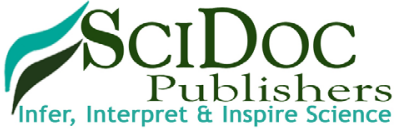

International Journal of Surgery and Research (IJSR)

ISSN 2379-156X

\title{
Why is Postoperative Atrial Fibrillation Difficult to Prevent and Treat: Potential Roles of Unrecognized Magnesium Deficiency and Release of Ceramide and Platelet-Activating Factor
}

Research Article

BM Altura ${ }^{1,2,3,4,5,}$, NC Shah ${ }^{1,5}$, GJ Shah ${ }^{1}$, JL Perez-Albela ${ }^{6}$, BT Altura ${ }^{1,3,4,5}$

${ }^{1}$ Department of Physiology and Pharmacology.

${ }^{2}$ Department of Medicine.

${ }^{3}$ Center for Cardiovascular and Muscle Research.

${ }^{4}$ The School of Graduate Studies in Molecular and Cellular Science, State University of New York Downstate Medical Center, Brooklyn, NY, USA. ${ }^{5}$ Bio-Defense Systems, Inc, Rockville Center, NY 11570.

${ }^{6}$ Instituto Bien de Salud, Lima, Peru.

Abstract

Heart failure is a major cause of morbidity and mortality whose costs impose staggering health-care costs and often lengthy hospitalizations. Post-operative atrial fibrillation (POAF) represents a leading cause for heart failure, paricularly after cardiac and lung surgeries. Although PAOF is a common cardiac arrhythmia, it is impossible to predict. As the worldwide population is aging, the incidence and prevalence of PAOF is growing. Identifying mechanisms for PAOF is attracting a considerable amount of research with no agreement on the mechanism(s). Our research on the heart and cardiovascular system, over the past 50-plus years, leads us to believe that major causes of PAOF may be an underlying magnesium deficiency $(\mathrm{MgD})$ coupled to a generation/ release of ceramides and platelet-activating factor (PAF). Herein, we review reasons behind our hypothesis and suggestions for testing its validity.

Keywords: PAF; Sphingolipids ; Heart Failure; Atherosclerosis; Inflammation.

\section{Introduction}

Post-operative atrial fibrillation (POAF) is the most prevalent complication after cardiac or lung surgery, occurring in about 20-50 percent of these patients [1-5]. This event often leads to increased morbidity, thromboembolisms, strokes and long-term mortality resulting in recurring hospitalizations and increased costs. Often the cause(s) of POAF is not known. Age, previous history of atrial fibrillation (AF), hypertension, diabetes, myocardial infarction, valvular heart disease, left ventricular hypertrophy, obesity, excessive drinking of alcohol and excessive smoking present great risk factors for development of POAF [15]. According to a number of reports, the incidence of cerebral infarction and heart failure can increase two-four - fold after PAOF [1-5]. Added to this, are a number of growing autopsy studies which demonstrate that many of the PAOF patients, who have died, have considerable atherosclerotic plaques on the walls of the coronary vessels leading to the idea that inflammatory events probably play an important role in the PAOF syndrome [5]. POAF is usually managed by digoxin, calcium channel blockers, betablockers, quinidine, amiodarone, direct current cardioversion, catheter ablation inside the heart, or appropriate rate control techniques to restore rhythm to normal [1-5]. Although digoxin is often utilized, it can present direct risks for POAF patients and has been associated with increased hospitalizations and mortalities $[6,7]$. Such data has raised serious concerns about use of digoxin, one of our oldest and most controversial drugs . Ever since 1935 [8], digoxin and cardiac glycosides have been known to deplete the human body and heart of magnesium $(\mathrm{Mg})$ [for review, see [9]]. Several studies have suggested that use of intravenous magnesium sulfate may be better than either betablockers, calcium channel blockers, or amiodarone [1, 5, 10-12]. This concept is currently under investigation by several groups in the USA and Europe.

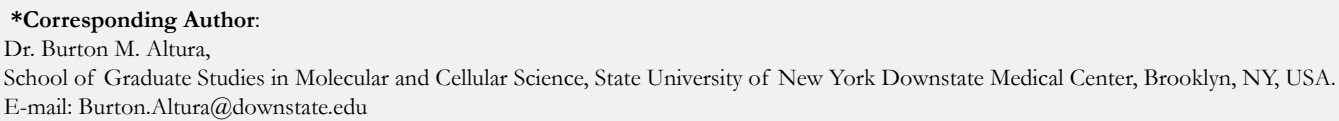

Citation: BM Altura, NC Shah, GJ Shah, JL Perez-Albela, BT Altura (2016) Why is Postoperative Atrial Fibrillation Difficult to Prevent and Treat: Potential Roles of Unrecognized Magnesium Deficiency and Release of Ceramide and Platelet-Activating Factor. Int J Surg Res. 3(3), 47-51. doi: http://dx.doi.org/10.19070/2379-156X-160010

Copyright: $\mathbf{B M}$ Altura ${ }^{\circ}$ 2016. This is an open-access article distributed under the terms of the Creative Commons Attribution License, which permits unrestricted use, distribution and reproduction in any medium, provided the original author and source are credited. 


\section{Why use intravenous $\mathrm{Mg}^{2+}$ ?}

$\mathrm{Mg}$ is a co-factor for more than 500 enzymes, and is the second most abundant intracellular cation after potassium. It is vital in numerous physiological, cellular and biochemical functions necessary for life [for reviews, see [13-15]].

Approximately 35 years ago, our laboratory suggested a progressive, dietary deficiency and/or metabolic-induced loss of $\mathrm{Mg}$ from the body (and heart), particularly during development of coronary arteries, could lead to coronary arterial vasospasm, arrhythmias, and sudden-cardiac death [16, 17]. Ever since this work was published, a number of clinical studies have been done and published which support this hypothesis, at least in adults [18-23]. Disturbances in diet are known to produce inflammatory lesions, promote lipid deposition and accelerated growth, and transformation of the smooth muscle cells in the vascular walls $[9,13,14,24-28]$. Reduction in dietary $\mathrm{Mg}$ intake has been demonstrated, experimentally, to result in atherogenesis, hypertension, cardiac dysfunctions, inflammations, and stroke of different types [9, 13-15, 29-33]; most of these phenomena usually being observed in patients scheduled for cardiac and lung surgeries. Hypermagnesemic diets have been shown to ameliorate atherogenesis, hypertension, cardiac dysfunctions, strokes and certain inflammatory conditions often found in patients scheduled for cardiac and lung surgeries [9, 13, 14, 24, 27-33]. In the Western World, dietary intake of $\mathrm{Mg}$ is subnormal, with shortfalls of between 65 and $225 \mathrm{mg}$ of $\mathrm{Mg} /$ day, depending upon geographic region [9, 13-15, 30, 34, 35]. Newly compiled NHANES data indicate that approximately $65 \%$ of the American population is $\mathrm{Mg}$ deficient [36]. Low $\mathrm{Mg}$ content in drinking water, found in areas of soft water and $\mathrm{Mg}$-poor soil, is associated with high incidences of ischemic heart disease (IHD), severe atherosclerosis, coronary vasospasm, hypertension, hyperlipidemia, and sudden-cardiac death [37-44]. The myocardial level of $\mathrm{Mg}$ has consistently been observed to be lower in subjects dying from IHD and suddencardiac death in soft water areas $[9,13,16,17,24,39,43]$.

Using sensitive, specific $\mathrm{Mg}^{2+}$ - ion electrodes, it has been shown that patients with IHD, patients scheduled for cardiac surgery or lung surgery, patients in cardiac failure, and patients with severe atherosclerosis exhibit significant depletion of serum/plasma and tissue levels of ionized, but not usually total $\mathrm{Mg}[15,27,33,45-$ 65]. Moreover, dietary deficiency of $\mathrm{Mg}$, under very controlled laboratory conditions, in rats and rabbits has been shown to cause vascular remodeling concomitant with atherogenesis and hypertension (e.g., arteriolar wall hypertrophy and alterations in arterial wall matrices) of unknown origin [67-69].

\section{$\mathrm{Mg}^{2+}$ modulates sphingolipid pathways in cardiac and vascular smooth muscle cells}

Although $\mathrm{Mg}$ depletion has long been known to result in cellular $\mathrm{Ca}^{2+}$-overload in cardiac and vascular smooth muscles (VSM) [7073], and $\mathrm{Mg}$ can act as a natural $\mathrm{Ca}^{2+}$ channel blocker [71-73], recent studies indicate that $\mathrm{Mg}^{2+}$ modulates sphingolipid pathways in both cardiac and VSM cells [27, 43, 44, 74-86]. Ceramides are sphingolipids known to be released as a consequence of sphingomyelinase (SMase) acting on sphingomyelin (SM), a component of all cell membranes, or as a consequence of the activation of serine palmitoyl transferase 1 and 2 (SPT 1 and SPT 2) (a de novo synthetic pathway) [87]. Ceramides are now thought to play important roles in fundamental processes such as inflammation, angiogenesis, membrane-receptor functions, cell proliferation, microcirculatory functions, cell adhesion, immunogenic responses, excitation-contraction coupling events in smooth muscles, and cell death (i.e., apoptosis) [27, 43, 44, 74-92]. SPT 1 and SPT 2 are the rate-limiting enzymes in the biosynthesis of sphingolipids [87]. More than 25 years ago, it was first demonstrated that SPT activity was increased in aortas of rabbits fed a high-cholesterol diet [93]. A short time after these latter studies were published, two of us showed that dietary deficiency of $\mathrm{Mg}$, in levels found commonly in Western World diets, vastly increased atherosclerotic plaque formations in rabbits fed high -cholesterol diets, whereas high dietary levels of $\mathrm{Mg}$ inhibited plaque formations [28]. SPT is a hetrodimer of $53-\mathrm{kDa}$ SPT-1 and 63-kDa SPT-2 subunits [87], both of which are bound to the endoplasmic reticulum [94]. An upregulation of SPT has been hypothesized to play a role in apoptosis, cell death events taking place in atherogenesis [79, 95].

Recently, we reported that $\mathrm{Mg}$ deficient $(\mathrm{MgD})$ diets given to rats for only 21 days results in upregulation of SMases (i.e., N-SMase, acid--SMase, and alkaline SMase), ceramide synthase, sphingomyelin synthase, SPT-1 and SPT-2 in a variety of cardiovascular tissues and cells as well decreased levels of SM and phosphatidylcholine (PC) [79-82, 84-86]. We also noted that MgD diets resulted in fragmentation of DNA $[81,86,96]$, release/ generation of a number of cytokines (and chemokines) [84], a release of cytochrome $\mathrm{C}$ [80] and lactic acid dehydrogenase [82], an increased expression of apototic protease factor-1 [81, 84], an activation of caspase-3 (needed for cell death) [79], all hallmarks of atherogenesis. When specific inhibitors of the SMases and SPT-1 (and SPT-2) were utilized, in primary cell cultures of VSM cells (including those from coronary arteries), exposed to low $\mathrm{Mg}^{2+}$ environments, we noted an inhibition and release of ceramides, inhibition of DNA fragmentation, inhibition of release of cytochrome $\mathrm{C}$ from the mitochondria, reduced expression of protease factor- 1 , an inhibition of activation of caspase-3, a decreased release of lactic acid dehydrogenase from the heart, reduced lipid peroxidation of cardiac muscle cells, and attenuation of release/generation of cytokines and chemokines [79-82, 84-86, 96, 97]. Working with perfused rat hearts, our laboratories found that low $\mathrm{Mg}^{2+}$ environments caused decreased perfusion pressures, decreases in stroke volume, marked decreases in coronary arterial flows, decreases in cardiac output, generation of ceramides, reductions in cardiac cellular ATP, phosphocreatine and $\mathrm{pH}$ [98] and generation of reactive oxygen species [99]. We, thus, believe that, collectively, these new studies on hearts and coronary arteries from animals on $\mathrm{MgD}$ diets support our hypothesis that generation and release of ceramides are pivotal molecules in the initiation of cellular and molecular events leading to coronary arterial (and coronary microcirculatory) ischemic changes, eventuating in inflammatory and atherogenic events producing atrial arrythmias and fibrillation.

During the performance of the foregoing in-vivo and in-vitro studies , using proton- nuclear magnetic resonance spectroscopy, we noted rapid formation of platelet-activating factor (PAF) and PAF-like lipid molecules [74]. 


\section{Magnesium deficient environments lead to forma- tion of PAF and its potential significance to atrial fibrillatory events}

PAF is known to play major roles in inflammatory responses and atherogenesis [for reviews, see [100-102]]. In addition, PAF is known to affect the heart and cardiac muscle cells in numerous ways [for reviews, see [101, 102]]. For example, PAF can produce coronary arterial vasoconstriction, lower arterial blood pressure, increase coronary vascular resistance, release several lipid-like molecules from the heart, reduce cardiac output, decrease cardiac contractility, alter atrial and papillary muscle chronotropicity and membrane action potentials, as well as alter potassium currents in isolated cardiomyocytes [for reviews, see [101, 102, 103]]. All of these attributes of PAF's actions on the heart and coronary vascular tree certainly would be more than enough to cause profound atrial fibrillation. Moreover, a variety of the circulating blood formed elements (e.g., polymorph nuclear leukocytes, platelets, basophils, and macrophages) and endothelial cells can elaborate PAF [101, 102]. Recently, we have found that coronary, cerebral and aortic VSM cells can also elaborate and release PAF [103]. There are a growing number of reports that both PAF and ceramides may result in transformation of VSM cells from one phenotype to another, as is typically found in the atherosclerotic process [for reviews, see [103-106]]. A number of investigators employing intravital microscopy techniques, similar to those used in our laboratories [for review, see [103]] have demonstrated that PAF increased the number of white blood cells in the microvessels concomitant with intense vasoconstriction-spasms with increasing concentrations of the putative lipid mediator (i.e., PAF), less leukocyte rolling , and increased adherence of the leukocytes to the endothelial surfaces with increased vascular-capillary permeability [for review, see [103]]. Using open and closed chambers implanted in rodent cerebral cortex and skeletal muscles, we have observed similar phenomena [103]. Interestingly, we have reported that ceramides produce almost similar phenomena in a variety of microvascular beds when studied by high-resolution video microscopy $[78,103]$. Collectively, these older and newer experimental studies could be used to advance our hypothesis that generation and release of both PAF and ceramides with underlying $\mathrm{MgD}$ states are more than likely involved in generation of atrial fibrillation after cardiac and lung surgery and may be major contributors in other types of patients presenting with atrial fibrillation.

\section{Importance of $\mathrm{Mg}$ supplemented drinking water and beverages for heart health}

Over the past two-plus decades, our laboratories have been investigating the utility of $\mathrm{Mg}$-supplemented or naturallyoccurring spring waters to avoid the pitfalls of dietary-and/ or metabolically-induced $\mathrm{MgD}$-states which affect heart health [e.g., see [79-82, 84-86, 96, 97]. Our results, so far, bolster the idea that water intake (e.g., from tap waters, well waters, bottled waters, beverages using tap/well/spring waters, or desalinated waters) in humans should contain at least $25-40 \mathrm{mg} /$ liter/day of $\mathrm{Mg}^{2+}$ [107]. A number of experiments done in our labs indicate that most, if not all of the cardiovascular manifestations (i.e., decreased cardiac output, decreased coronary arterial flows, lipid peroxidation of cardiac muscle membranes, synthesis/release of toxic sphingolipids, cytokines and chemokines, mitochondrial release of cytochrome $\mathrm{C}$, increased $\mathrm{Ca}^{2+}$ entry and overload, apoptosis, etc) observed in hearts of experimental animals can be prevented or ameliorated when imbibing drinking waters with appropriate amounts of $\mathrm{Mg}^{2+}[79-82,84-86,96,97]$. We believe the latter inclusion in our diets should go a long-way towards the prevention and amelioration of heart arrthymias and fibrillations . Instituting such a daily regimen should also prevent a number of underlying risk factors for PAOF (e.g., drinking of alcoholic beverages, excessive smoking, and aging). Interestingly, on the basis of our work in animals, the World Health Organization has suggested people should consume drinking waters containing our recommended $25-40 \mathrm{mg} /$ liter/day of $\mathrm{Mg}^{2+}$ [108]. It is our hope that a large scale appropriately-controlled clinical trial can be instituted in patients scheduled for cardiac and lung surgeries to test our hypothesis.

\section{Future considerations}

Although the exact underlying cause(s) of the high frequency of $\mathrm{PAOF}$ in patients scheduled for heart or lung surgeries remains to be determined, a number of animal models (in mice, goats, rabbits and dogs) have been utilized to gain insights into possible causes of atrial fibrillation (AF) [for reviews, see [2, 4, 5]]. A number of these models have employed knock-out and knock-down mice for several potential target genes. Several of these mouse AF models could be examined to determine if they are $\mathrm{MgD}$ (particularly decreased ionized $\mathrm{Mg}$ levels) and have excess PAF and ceramide synthesis and release as a test of our hypothesis. In addition, a clinical study should be undertaken to determine ionized $\mathrm{Mg}$ levels, ceramide levels, and PAF levels prior to and after cardiac and lung surgeries to examine any correlations between these parameters before (and after surgeries) to frequency of PAOF. Moreover, it would be prudent, we believe, to undertake clinical blinded- trials to determine whether pretreatment of patients, scheduled for cardiac or lung surgery, would benefit from pretreatment with selective blockers of ceramide generation/ release and PAF generation/release along with administration of oral and intravenous $\mathrm{Mg}$. Only time will tell whether these human and animal studies will prove to validate our hypothesis.

\section{References}

[1]. Prystowsky EN, Katz A ( 1998) Atrial fibrillation. In: Comprehensive Cardiovascular Medicine. Lippincott Publ ,Philadelphia.1827-1859.

[2]. Iqbal MB, Taneja AK, Lip GY, Flather M (2005) Recent developments in atrial fibrillation [review]. Br Med J 330(7485): 238-243.

[3]. Riber LP, Larsen TB, Christensen TD (2014) Postoperative atrial fibrillation prophylaxis after lung surgery: Systemic review and meta-analysis. Ann Thorac Surg 98(6): 1989-1997.

[4]. Zhang L, Gao S (2016) Systematic review and meta-analysis of atrial fibrillation prophylaxis after lung surgery. J Cardiovasc Pharmacol 67(4): 351-367.

[5]. Omae T, Kanmura Y (2102) Management of postoperative atrial fibrillation. J Anesth 26(3): 429-437.

[6]. Ritchie AJ, Danton M, Gibbons JR (1992) Prophylactic digitalisation in pulmonary surgery. Thorax 47(1): 41-43.

[7]. Kaiser A, Zund G, Weder W, Largiader F (1994) Preventive digitalis therapy in open thoracotomy [in German]. Helv Chir Axta 60(6): 913-917.

[8]. Zwillinger L (1935) Magnesium and the heart. Klin Wschr 14: 1429-1433.

[9]. Altura BM, Altura BT (1985) New perspectives on the role of magnesium in the pathophysiology of the cardiovascular system. I. Clinical aspects. Magnesium 4(5-6): 226-244.

[10]. Satur CM (1997) Magnesium and cardiac surgery. Ann Roy Coll Surg Engl 79(5): 349-354

[11]. Vyvyan HA, Mayne PN, Cutfield GR (1994) Magnesium flux and cardiac surgery: a study of the relationship between magnesium exchange, serum magnesium levels and post-operative arrhythmias. Anaesthesia 49(3): 245249. 
[12]. Miller S, Crystal E, Garfinkle M, Lau C, Lashevsky I, Connolly SJ (2005) Effects of magnesium on atrial fibrillation after cardiac surgery: a meta-analysis. Heart 91(5): 618-623.

[13]. Seelig MS, Rosanoff A (2003) The Magnesium Factor. The Penguin Group New York.

[14]. Dean C (2014) The Magnesium Miracle.(3rd edn),Ballantine Books, New York.

[15]. Altura BM, Altura BT (2016) Importance of ionized magnesium measurements in physiology and medicine and the need for ion-selective electrodes. J Clin Case Studies 1(2): 1-4. doi http://dx.doi. org/10.16966/24714925.111

[16]. Altura BM (1979) Sudden-death ischemic heart disease and dietary magnesium intake: Is the target site coronary vascular smooth muscle? Med Hypotheses 5(8): 843-848.

[17]. Turlapaty PDMV, Altura BM (1980) Magnesium deficiency produces spasms of coronary arteries: relationship to etiology of sudden death ischemic heart disease. Science 208(4440): 198-200.

[18]. Kimura T, Yasue H, Sakaino N, Rokutanda M, Jougasaki M, et al (1989) Effects of magnesium on the tone of isolated human coronary arteries. Circulation 79(5): 1118-1124

[19]. Goto K, Yasue H, Okukura K (1990) Magnesium deficiency detected by intravenous loading test in variant angina pectoris. Am J Cardiol 65(11): 709-712.

[20]. Simko F (1994) Pathophysiological aspects of the protective effect of magnesium in myocardial infarction. Acta Med Hung 50(1-2): 55-64

[21]. Satake K, Lee JD, Shinizu H, Ueda T, Nakamura T (1996) Relation between severity of magnesium deficiency and frequency of anginal attacks in men with variant angina. Am J Cardiol 28(4): 897-902.

[22]. Sueda S, Fukuda H, Watanabe K (2001) Magnesium deficiency in patients with recent myocardial infarction and provoked coronary artery spasm. Jap Circ J 65(7): 643-648.

[23]. Minato N, Katayama Y, Sakaguchi M, Itoh M (2006) Perioperative coronary artery spasm in off-pump coronary bypass grafting and its possible relation with perioperative hypomagnesemia. Ann Thorac Cardiovasc Surg 12(1): 32-36.

[24]. Seelig MS (1980) Magnesium Deficiency in the Pathogenesis of Disease: Early Roots of Cardiovascular, Skeletal, and Renal Abnormalities . (1st edn), Springer US Plenum, New York. 488.

[25]. Berenson GS, Srinivassan SR, Bao W, Newman WP, Tracey RE, et al. (1998) Association between multiple cardiovascular risk factors and atherosclerosis in children and young adults. N Engl J Med 338(23): 1650-1658.

[26]. Kumar V, Abbas K, Fasuto N, Aster JC (2010) Robbins and Cotran Pathologic Basis of Disease. (8th edn) ,Elsevier, New York, USA.

[27]. Altura BM, Altura BT (2007) Magnnesium: forgotten mineral in cardiovascular biology and angiogenesis, New Perspectives in Magnesium Research. Springer London, UK. 239-260

[28]. Altura BT, Brust M, Bloom S, Barbiur RL, Stempak J, et al. (1990) Magnesium dietary intake modulates blood lipid levels and atherogenesis. Proc Nat Acad Sci USA 87(5) : 1840-1844.

[29]. King JL, Miller RJ, Blue JP Jr, O'Brien WD Jr, Erdman JW Jr (2009) Inadequate dietary magnesium intake increases atherosclerotic plaque development in rabbits. Nutr Res 29(5) : 343-349.

[30]. de Baaj JHF, Henderop JG, Bindels RJ (2015) Magnesium in man: Implications for health and disease. Physiol Rev 95(1): 1-46.

[31]. Luthringer C, Rayssiguier Y, Gueux E, Berthelot A (1988) Effect of moderate magnesium deficiency on serum lipids, blood pressure and cardiovascular reactivity in normotensive rats. Br J Nutr 59(2): 243-250.

[32]. Saris NE, Mervaala E, Karppanen H, Khawaja jA, Lewenstam A (2000) Magnesium: an update on physiological, clinical and analytical aspects. Clin Chim Acta 294(1-2): 1-26.

[33]. Altura BT, Altura BM (1991) Measurement of ionized magnesium in whole blood, plasma and serum with a new ion-selective electrode in healthy and diseased human subjects. Magne Trace Elem 10(2-4): 90-98.

[34]. Ford ES, Mokdad AH (2003) Dietary magnesium intake in a national sample of US adults. J Nutr 133(9): 2879-2882

[35]. Mosfegh A, Goldman J, Abuja J , Rhodes D, La Comb R (2009) What We Eat in America. NHANES 2005-2006: usual Nutrient Intakes from Food and Water Compared to 1997 Dietary Reference Intakes for Vitamin D, Calcium, Phosphorus, and Magnesium. U.S. Department of Agricultural Research.

[36]. NHANES 2009-2012 (2016) Dietary Reference Intakes for Vitamin D, Calcium, Phosphorus, and Magnesium. U.S. department of Agricultural Research Service( in press). Washington, DC.

[37]. Marier JM, Neri LC (1985) Quantifying the role of magnesium in the iterrelationship between human mortality/ morbidity and water hardness. Magnesium 4(2): 53-59.

[38]. Leary WP (1986) Content of magnesium in drinking water and deaths from ischaemic heart disease in White South Africans. Magnesium 5(3-4): 150153.

[39]. Chipperfield B, Chipperfield JR (1979) Relation of myocardial metal concentration to water hardness and death-rates from ischaemic heart disease. Lancet 2(1845): 709-712.

[40]. Marx A, Neutra RR (1997) Magnesium in drinking water and ischemic heart disease. Epidemiol Rev 19(2): 258-272.

[41]. Rubenowitz E, Molin I, Axelsson G, Rylander R (2000) Magnesium in drinking water in relation to morbidity and mortality from acute myocardial infarction. Epidemiology 11(4); 416-421.

[42]. Altura BM, Altura BT (1990) Magnesium and the cardiovascular system: Experimental and clinical aspects updated. Metals in Biological Systems 26: 359-416

[43]. Altura BM, Altura BT (1995) Magnesium and cardiovascular biology: an important link between cardiovascular risk factors and atherogenesis. Cell Mol Biol Res 41(5): 347-359.

[44]. Altura BM, Altura BT (1995) Magnesium in cardiovascular biology. Sci Am.Sci Med 2: 28-37.

[45]. Altura BT, Shirey TL, Young CC, Hiti J, Dell'Orfano K, et al. ( 1992) A new method for the rapid determination of ionized $\mathrm{Mg}^{2+}$ in whole blood, serum and plasma. Methods Find Exp Clin Pharmacol 14(4): 297-304.

[46]. Handwerker SM, Altura BT, Royo B, Altura BM (1993) Ionized magnesium and calcium levels in umbilical cord serum of pregnant women with transient hypertension during labor. Am J Hypertens 6(6 Pt 1): 542-545.

[47]. Altura BM, Altura BT (1994) Role of magnesium and calcium in alcoholinduced hypertension and strokes as probed by in vivo television microscopy, digital image microscopy, optical spectroscopy, 31P-NMR spectroscopy and a unique magnesium ion-selective electrode. Alcohol Clin Exp Res 18(5): 1057-1068.

[48]. Markell MS, Altura BT, Barbour RL, Altura BM (1993) Ionized and total magnesium levels in cyclosporin-treated renal transplant recipients: relationship with cholesterol and cyclosporin levels. Clin Sci 85(3): 315-318.

[49]. Markell MS, Altura BT, Sarn Y, Delano BG, Hudo O, et al. (1993) Deficiency of serum ionized magnesium in patients receiving hemodialysis or peritoneal dialysis. ASAIO J 39(3): 801-804.

[50]. Resnick LM, Altura BT, Gupta RK, Alderman MH, Altura BM (1993) Intracellular and extracellular magnesium depletion in type 2 diabetes(noninsulin-dependent)diabetes mellitus. Diabetologia 36(8): 767-770.

[51]. Altura BM, Lewenstam A (1994) Unique Magnesium-Sensitive Ion Selective Electrodes. Scand J Clin Lab Invest 54(217): 1-100.

[52]. Altura BM, Altura BT (1994) Role of magnesium in pathophysiological processes and the clinical utility of magnesium ion-selective electrodes. Scand J Clin Lab Invest 54(224): 211-234.

[53]. Bardicef M, Bardicef O, Sorokin Y, Altura BM, Altura BT, et al. (1995) Extracellular and intracellular magnesium depletion in pregnancy and gestational diabetes. Am J Obst Gynecol 172(3): 1009-1013.

[54]. Altura BT, Memon ZI, Zhang A, Cracco RQ, Altura BM (1997) Low levels of serum ionized magnesium found early after stroke which result in rapid elevation in cytosolic free calcium and spasm in cerebral vascular smooth muscle cells. Neurosci Lett 230(1): 37-40.

[55]. Resnick LM, Bardicef O, Altura BT, Alderman MH, Altura BM (1997) Serum ionized magnesium : Relation to blood pressure and racial factors. Am J Hypertens 10(12 Pt 2): 1420-1424.

[56]. Seelig MS, Altura BM (1997) How best to determine magnesium requirements: Need to consider cardiotherapeutic drugs that affect its retention. J Am Coll Nutr 16(1): 4-6.

[57]. Altura BM, Altura BT (1999) Association of alcohol in brain injury, headache and stroke with brain tissue and serum levels of ionized magnesium: A review of recent findings and mechanisms of action. Alcohol 19(2): 119130.

[58]. Muneyyrici -Delale O, Nacharaju VL, Jalou S, Rahman M, Altura BM, Altura BT (2001) Divalent cations in women with PCOS: Implications for cardiovascular disease. Gynecol Endocrinol 15(3): 199-201.

[59]. Handwerker SM, Altura BT, Jones KY, Altura BM (1995) Maternal-fetal transfer of ionized magnesium during stress of labor and delivery: a human study. Am J Coll Nutr 14(4): 376-381.

[60]. Scott VL, DeWolf AM, Kang Y, Altura BT, Virji MA, Altura BM (1996) Ionized hypomagnesemia in patients undergoing orthotopic liver transplantation: a complication of citrate intoxication. Liver Transpl Surg 2(5): 343 347.

[61]. Fogh-Andersen N, Altura BM, Altura BT, Sigaard-Andersen O (1996) Changes in plasma ionized calcium and magnesium in blood donors after donation of $450 \mathrm{ml}$ blood. Effects of hemodilution and Donnan equilibrium. Scand J Clin Lab Invest 56(224): 245-250.

[62]. Djurhuus S, Henriksen JE, Klitgaard NA, Blaabjerg O, Thye-Ron P, et al. (1999) Effect of moderate improvement in metabolic control on magnesium and lipid concentrations in patients with type i diabetes. Dibetes Care 
22(4): 546-554.

[63]. Djurhuus S, Klitgaard NA, Pedersen KK, Blaabjerg O, Altura BM, Altura BT, et al. (2001) Magnesium reduces insulin-stimulated glucose uptake and serum lipid concentrations in type 1 diabetes. Metabolism 50(12): 14091417

[64]. Altura RA, Wang WC, Wynn L, Altura BM, Altura BT (2002) Hydroxyurea therapy associated with declining serum levels of magnesium in children with sickle cell anemia. J Pediatr 140(5): 565-569.

[65]. Zehtabchi S, Sinert R, Rinnert S, Chang B, Hennis R, et al. (2004) Serum ionized magnesium levels and ionized calcium to magnesium ratios in adult patients with sickle cell anemia. Am J Hematol 77(3): 215-222.

[66]. Apostol A, Apostol R, Ali M, Choi A, Ehsuni N, Altura BT, Altura BM (2010) Cerebral spinal fluid and serum ionized magnesium and calcium levels in preeclamptic women during administration of magnesium sulfate. Fertil Steril 94(1): 276-282.

[67]. Altura BM, Altura BT, Gebrewold A, Ising H, Gunther T (1984) Magnesium deficiency and hypertension: correlation between magnesium deficiency diets and microcirculatory changes in situ. Science 223(4642): 1315-1317.

[68]. Altura BM, Altura BT, Gebrewold A, Gunther T, Ising H (1992) Noiseinduced hypertension and magnesium: relationship to microcirculation and calcium. J Appl Physiol 72(1): 194-202.

[69]. Altura BM, Altura BT (1996) Magnesium as an extracellular signal in cardiovascular pathobiology. J Jap Magnes Res 15: 17-32.

[70]. Altura BM, Altura BT (1971) Influence of magnesium on drug-induced contractions and ion content in rabbit aorta. Am J physiol 220: 938-944.

[71]. Altura BM, Altura BT (1974) Magnesium and contraction of arterial smooth muscle. Microvasc Res 7(2): 145-155.

[72]. Altura BM, Altura BT (1981) Magnesium modulates calcium entry and contractility in vascular smooth muscle. In The Mechanism of Gated Calcium Transport Across Biological Membranes. Academic Press, New York, 137-145.

[73]. Altura BM, Gebrewold A, Altura BT, Brautbar N (1996) Magnesium depletion impairs cardiac carbohydrate and lipid metabolism and cardiac bioenergetics and raises myocardial calcium content in vivo: relationship to etiology of cardiac diseases. Biochem Mol Biol Int 40(6); 1183-1190.

[74]. Morrill GA, Gupta RK, Kostellow AB, Ma GY, Zhang A, et al. (1997) $\mathrm{Mg}^{2+}$ modulates membrane lipids in vascular smooth muscle : a link to atherogenesis. FEBS Lett 408(2): 191-194.

[75]. Morrill GA, Gupta RK, Kostellow AB, Ma GY, Zhang A, et al. (1998) $\mathrm{Mg}^{2+}$ modulates membrane sphingolipids and lipid second messengers in vascular smooth muscle cells. FEBS Lett 440(1-2): 167-171.

[76]. Zheng T, Li W, Wang J, Altura BT, Altura BM (1999) Effects of neutral sphingomyelinase on phenylephrine-induced vasoconstriction and $\mathrm{Ca}^{2+}$ mobilization in rat aortic smooth muscle. Eur J Pharmacol 391(1-2): 127-135.

[77]. Zheng T, Li W, Wang J, Altura BT, Altura BM (2000) Sphingomyelinase and ceramide analogs induce contraction and rises in $\left[\mathrm{Ca}^{2+}\right] \mathrm{i}$ in canine cerebral vascular muscle. Am J Physiol Heart Circ Physiol 278(5): H1421H1428.

[78]. Altura BM, Gebrewold A, Zheng T, Altura BT (2002) Sphingomyelinase and ceramide analogs induce vasoconstriction and leukocyte-endothelial interactions in cerebral venules inthe intact brain: insight mechanisms and possible relation to brain injury and stroke. Brain Res Bull 58(3): 271-278.

[79]. Altura BM, Shah NC, Jiang XC, Li Z, Perez-Albela JL, Altura BT (2009) Short-term magnesium deficiency results in decreased levels of serum sphingomyelin, lipid peroxidation, and apoptosis in cardiovascular tissues. Am J Physiol Heart Circ Physiol 297(1): H86-H92.

[80]. Altura BM, Shah NC, Li Z, Jiang XC, Perez-Albela JL, Altura BT (2010) Magnesium deficiency upregulates serine palmitoyltransferase (SPT 1 and SPT 2) in cardiovascular tissues: relationship to serum ionized $\mathrm{Mg}$ and cytochrome C. Am J Physiol Heart Circ Physiol 299(3): H932-H938.

[81]. Altura BM, Shah NC, Li Z, Jiang XC, Zhang A, et al. (2010) Short-term magnesium deficiency upregulates sphingomyelin synthase and $\mathrm{p} 53$ in cardiovascular tissues and cells: relevance to the de novo synthesis of ceramide. Am J Physiol Heart Circ Physiol 299(6): H2046-H2055.

[82]. Shah NC, Liu JP, Iqbal J, Hussain M, Jiang XC, et al. (2011) Mg deficiency results in modulation of serum lipids, glutathione, and NO synthase isozyme activation in cardiovascular tissues: relevance to de novo synthesis of ceramide, serum Mg and atherogenesis. Int J Clin Exp Med 4(2):103-118.

[83]. Zheng T, Li W, Altura BT, Shah NC, Altura BM (2011) Sphingolipids regulate $\left[\mathrm{Mg}^{2+}\right]_{0}$ uptake and $\left[\mathrm{Mg}^{2+}\right] \mathrm{i}$ content in vascular smooth muscle cells : potential mechanisms and importance to membrane transport of $\mathrm{Mg}^{2+}$. Am J Physiol Heart Circ Physiol 300(2): H486-H492.

[84]. Altura BM, Shah NC, Shah GJ, Zhang A, Li W, et al. (2012) Short-term magnesium deficiency upregulates ceramide synthase in cardiovascular tissues and cells: cross-talk among cytokines, $\mathrm{Mg}^{2+}, \mathrm{NF}-\mathrm{kB}$ and de novo ceramide. Am J Physiol Heart Circ Physiol 302(1): H319-H332.

[85]. Altura BM, Shah NC, Shah GJ, Li W, Zhang A, et al. (2013) Magnesium deficiency upregulates sphingomyelinases in cardiovascular tissues and cells: cross-talk among proto-oncogenes, $\mathrm{Mg}^{2+}, \mathrm{NF}-\mathrm{KB}$ and ceramide and their potential relationships to resistant hypertension, atherogenesis and cardiac failure. Int J Clin Exp Med 6(10): 861-879.

[86]. Shah NC, Shah GJ, Li Z, Jiang XC, Altura BT, Altura BM (2014) Shortterm magnesium deficiency downregulates telomerase, upregulates neutral sphingomyelinase and induces oxidative DNA damage in cardiovascular tissues: relevance to atherogenesis, cardiovascular diseases and aging. Int J Clin Exp Med 7(3): 497-514.

[87]. Merrill AH Jr, Jones DD (1990) An update of the enzymology and regulation of sphingolipid metabolism. Biochim Biophys Acta 1044(1): 1-12.

[88]. Haimovitz-Friedman A, Kolesnick RN, Fuks Z (1997) Ceramide signaling in apoptosis. Br Med Bull 53(3): 539-553.

[89]. Hannun YA, Obeid LM (2002) The ceramide -centric universe of lipidmediated cell regulation: stress encounters of the lipid kind. J Biol Chem 277(29): 25847-25850

[90]. Andrieu-Abadie N, Gouaze V, Salvayre R, Levade T (2001) Ceramide in apoptosis signaling: relationship with oxidative stress. Free Radic Biol Med 31(6): 717-728

[91]. Auge N, Negre-Salvayre A, Salvayre R, Levade T (2000) Sphingomyelin metabolites in vascular signaling and atherosclerosis. Prog Liupid Res 39(3): 207-239.

[92]. Pandey S, Murphy RE, Agrawal DK (2007) Recent advances in the immunobiology of ceramide. Exp Mol Pathol 82(3): 298-309.

[93]. Williams RD, Sgoutas DS, Zaatari GS (1986) Enzymology of long-chain base synthesis by aorta: induction of serine palmitoyltransferase activity in rabbit aorta during atherogenesis. J Lipid Res 27(7): 763-770.

[94]. Yasuda S, Nishjima M, Hanada K (2003) Localization , topology, and function of the LCB1 subunit of serine palmitoyltransferase in mammalian cells. J Biol Chem 278(6): 4176-4183.

[95]. Hanada K (2003) Serine palmitoyltransferase, a key enzyme of sphingolipid metabolism. Biochim Biophys Acta 163(1-3): 16-30.

[96]. Altura BM, Shah NC, Shah GJ, Perez-Albela JL, Altura BT (2016) Magnesium deficiency results in oxidation and fragmentation of DNA, downregulation of telomerase activity, and ceramide release in cardiovascular tissues and cells: Potential relationship to atherogenesis, cardiovascular diseases and aging. Int J Diabetol Vasc Dis 4(1e): 1-5.

[97]. Altura BM, Shah NC, Shah GJ, Zhang A, et al. ( 2014) Short-term Mg deficiency upregulates protein kinase $\mathrm{C}$ isoforms in cardiovascular tissues and cells; relation to NF-kB, cytokines, ceramide salvage sphingolipid pathway and PKC-zeta: hypothesis and review. Int J Clin Exp Med 7(1): 1-21.

[98]. Altura BM, Barbour RL, Dowd TL, Wu F, Altura BT, Gupta RK (1993) Low extracellular magnesium induces intracellular free $\mathrm{Mg}$ deficits, ischemia, depletion of high-energy phosphates and cardiac failure in intact working rat hearts: a 31P-NMR study. Biochim Biophys Acta 1182(3): 329-332.

[99]. Wu F, Altura BT, GaoJ, Barbour RL, Altura BM (1994) Ferrylmyoglobin formation induced by acute magnesium deficiency in perfused rat heart causes cardiac failure. Biochim Biophys Acta 1225(2): 158-164.

[100]. Fruhwirth GO, Loidl A, Hermetter A (2007) Oxidized phospholipids: from molecular properties to disease. Biochim Biophys Acta 1772(7): 718-736.

[101]. Prescott SM, Zimmerman GA, Stafforini DM, McIntyre TM (2000) Platelet-activating factor and related lipid mediators. annu Rev biochem 69: 419445.

[102]. Montrucchio G, Alloatti G, Camussi G (2000) Role of platelet-activating factor in cardiovascular pathophysiology. Physiol Rev 80(4): 1669-1699.

[103].Altura BM, Li W, Zhang A, Zheng T, Shah NC, et al. (2016) The expression of platelet-activating factor is induced by low extracellular $\mathrm{Mg}^{2+}$ in aortic, cerebral and neonatal coronary vascular smooth muscle; cross-talk with ceramide production, NF-kB and proto-oncogenes : Possible links to atherogenesis and sudden cardiac death in children and infants, and aging: Hypothesis, review and viewpoint. Int J Cardiol Res 3(1): 47-67.

[104].Hage-Sleiman R, Esmerian MO, Kobeissey H, Dbaibo G (2013) p53 and ceramide as collaborators in the stress response. Int J Mol Sci 14(3): 4982 5012 .

[105].Aguilera-Romero A, Gehin C, Reizman H (2014) Sphingolipid homeostasi in the web of metabolic routes. Biochim Biophys Acta 1841(5): 647-656.

[106]. Altura BM, Gebrewold A, Shah NC, Shah GJ, Altura BT (2016) Potential roles of magnesium deficiency in inflammation and atherogenesis: importance and cross-talk of platelet-activating factor and ceramide. J Clin Exp Cardiol 7(3): in press.

[107].Altura BM, Altura BT (2009) Atherosclerosis and magnesium . In Calcium and Magnesium in Drinking -Water. Public Health Significance. WHO, Geneva,75-81.

[108]. Calcium and Magnesium in Drinking -Water. Public Health Significance. WHO, Geneva, 2009 